\title{
MODEL OF SOCIAL AND ECONOMIC CHARACTERISTICS OF MSMES IN UTILIZING ONLINE MEDIA TO INCREASE PEOPLE'SPOWER IN BATANG KUIS DISTRICT
}

\author{
Julita $^{1}$, Nel Arianty ${ }^{2}$ Rahmad Bahagia ${ }^{3}$ \\ ${ }^{1,2,3}$ Faculty of Economics and Business, Universitas Muhammadiyah Sumatera Utara \\ E-mail: julita@umsu.ac.id
}

\begin{abstract}
The purpose of the study was to determine and analyze the effect of Social Characteristics on Purchasing power, to find out and analyze the influence of MSME Economy on the Purchasing power, to find out and analyze the influence of online media on Purchasing power, to determine and analyze the influence, Social Characteristics, Economics of SMEs, and Online Media onPurchasing powerto the community in Batang Kuis District. The results showed that social characteristics had no significant effect on purchasing power. This shows the influence of the digital era that has been widely carried out in buying and selling interactions, so that direct social interaction is very rarely carried out. The MSME economy has a significant effect on purchasing power. This shows the influence of the community's economy that influences the purchase of a product. Online media has a significant effect on purchasing power. This shows the influence of social media which has been widely used by the community in carrying out activities including buying the necessary needs through social media.
\end{abstract}

Keywords: Social Characteristics, MSME Economy, Online Media, Purchasing Power

\section{PRELIMINARY}

The role of MSMEs according to The World Bank are; first, increasing the atmosphere of competition and entrepreneurship, besides that it also has other advantages in the efficiency of the economic sector, innovation and productivity growth. Second, in general, MSMEs are more productive than large businesses. In Indonesia, the contribution of MSMEs to GDP is $79.20 \%$. In addition, in terms of contribution to Indonesia's GDP, MSMEs have contributed up to more than $60 \%$ of the total GDP in 2010-2012. Seeing the strong position of MSMEs in the Indonesian economy, there is enough reason to analyze in more depth how MSMEs can develop and survive in a volatile economy. These macro-environmental pressures lead business institutions to appreciate the important role of the ability to build business networks. Through this business network flows information that is important and useful for business development. Information in business networks is an important knowledge in an increasingly competitive market. Knowledge when used properly can improve an organization's ability to 
compete (Ferdinand, 2008). The development of the software industry is influenced by three main factors, namely; people, information, and technology. In its development, this industry is still on the scale of Micro, Small and Medium Enterprises (MSMEs) with the category of software service industry (Setiarso, 2006).

Reality in the field shows that, most MSMEs in Indonesia, have some of the same problems, one of which is the lack of knowledge about marketing, caused by the limited information that can be reached by MSMEs about the market. Marketing can be done through interactive online computer systems, which connect buyers and sellers electronically, which is the most important part of e-commerce or the electronic trading process using websites, blogs or online media.

Online media can be a medium that connects entrepreneurs and consumers. Consumers can easily get information about the product. Consumers no longer have difficulty in getting the latest information about the products sold by MSMEs. Online media facilitates interaction between consumers and entrepreneurs. For SMEs, online media is used to develop businesses, increase product sales, communicate with consumers, and develop a wider market network.(Lathifah \& Lubis, 2018).

Through online media, MSMEs can consistently provide the best, by maintaining market trends, providing relevant information in an interesting manner, at any time, anywhere in several media, and providing appropriate services. Promotion is a part of communication that consists of company messages designed to stimulate awareness, interest, and ends with a purchase action made by the customer for the product or service (Kotler, 2003).

according to (Moriansyah, 2015), online media can be used to get information or recommendations from the network or community that creates a desire to buy the product. When promoting through online media optimally, information about these products will be widely spread and will bring in more consumers so that it can affect the company's income. With good marketing, it will make it easier for the audience to search for any products that are produced by business people. This makes researchers want to know more deeply how the relationship between the use of online media as a promotional medium and changes in business development in MSMEs.

\section{THEORY DESCRIPTION}

\section{1) Social Characteristics}

The self-ability in question is indicated by the following characteristics: age, gender, level of formal education, level of informal education, and social interaction. The basic characteristics of a person can determine competence in achieving the best and effective work results based on criteria in a particular job or condition (Spencer, LM, 1993).

Social characteristics include a) Education, namely the level of education that the respondent has taken, namely not attending school, graduating from elementary school, graduating from junior high school. b) Knowledge is information or information that is known or realized by someone. c) The working relationship system is the relationship between scavengers and lapak or scavenger bosses in depositing or selling levies (Sutardji, 2009). 


\section{2) Online media}

The benefits of the internet are increasingly felt for its users who cannot be separated from this internet world. For example, internet marketers, bloggers, bloggers, and now online stores are increasingly having a place in the eyes of consumers who are looking for certain goods. The Ministry of Communication and Informatics (Kemkominfo) stated that currently, internet users in Indonesia have reached 82 million people. With this achievement, Indonesia is ranked 8th in the world (Kominfo, 2013). In the digital era, online media has now become a trend in marketing communications. Online media is a medium, with its users being able to easily participate, share, and create content including blogs, social networks, wikis, forums and virtual worlds. Blogs, social networks and wikis are the most common forms of social media used by people around the world (Kaplan, Andreas, 2010).

Online media is a group of internet-based applications that are built on the ideological and technological framework of Web 2.0, and allow the creation of the exchange of information content from internet users. (Moch Hari Purwidiantoro, Dany Fajar Kristanto SW, 2006). The development of information technology is growing rapidly. Most of the activities of Micro, Small and Medium Enterprises (MSMEs) utilize information technology to run their business. The increasing number of competitors becomes a consideration for business actors to innovate in winning the competition. The right marketing communication strategy is used to be able to reach the target market share so as to increase sales (Mohamad Trio Febriyantoro, 2019). Buying and selling with online media also allows everyone to sell a variety of products without having to spend capital by becoming a reseller. This pattern is very strategic to be used to market MSME products. Through online, MSMEs do not need to prepare capital to set up outlets, pay employees (Rafsanjani, 2018). Offering and selling online has various advantages, including increasing profit margins. The market share is getting wider, the sales volume is increasing, and the promotion costs can be minimized (Husin et al., 2019). Business communication with online media in the digital era 4.0 makes a way out for MSMEs in Kab. Gunung Mas, because today's communication has entered hypermedia where communication is strongly supported by communication technology devices (Diah AP, Partini, 2018).

\section{3) Purchasing power}

Purchasing power is the ability of consumers to buy the amount of goods demanded in a certain market, at a certain level of income and in a certain period. (Putong, 2010). Purchasing power parity theory focuses on the relationship of inflation to the exchange rate, that the exchange rate will adjust over time to reflect the difference in inflation between two countries, consequently the purchasing power of consumers to buy domestic products will be equal to their purchasing power to buy foreign products. overseas products(Madura, 2000). Purchasing power is closely related to inflation and the amount of income and expenditure which leads to a picture of the level of welfare enjoyed by the community as a result of improving economic activity. The higher the purchasing power of the people, it can be said that the higher the level of income (Rosyadi, 2019). 
Here are some factors that can affect consumer purchasing power, among others, namely Dr. Supawi, 2012 in the journal (Eva Margaret Sarah Nainggolan, 2019) :

a) Income Level

Income is a reward from someone for the energy or thoughts that are donated, usually in the form of wages or salaries. The higher a person's income, the higher his purchasing power and the more diverse the needs that must be met, and vice versa.

b) Level of education

The higher a person's education, the higher the needs he wants to fulfill.

c) Level of Need

Everyone's needs are different. Someone who lives in the city, his purchasing power will be higher when compared to those who live in the village.

d) People's Habits

In this modern era, there is a tendency of consumerism in society. The application of an economic lifestyle, namely by buying goods and services that are really needed, has indirectly increased the welfare of life.

e) Price of goods

If the price of goods increases, the purchasing power of consumers tends to decrease, while if the price of goods decreases, the purchasing power of consumers will increase. This is in accordance with the law of demand.

f) Mode

Goods that have just become fashionable in society will usually sell well in the market so that consumption increases. Thus the mode can affect consumption.

\section{RESEARCH METHODS}

\section{1) Research Flowchart}

This research flow chart shows the implementation process during this research. Through field studies, it will be known and identified problems that are often faced by MSME actors with models of social and economic characteristics in the use of online media to increase people's purchasing power. After that, field studies were carried out through observation and interviews. This research is a basic research. The stages of this research procedure can be seen in the development research flow chart as follows: 


\begin{tabular}{|c|c|c|}
\hline \multicolumn{3}{|c|}{ My Previous Research } \\
\hline Activity & Indicator & Output \\
\hline $\begin{array}{l}\text { Development of } \\
\text { Entrepreneur Independence } \\
\text { Model in Improving } \\
\text { Entrepreneur's } \\
\text { Performance in Lubuk } \\
\text { Pakam. District }\end{array}$ & $\begin{array}{l}\text { 1. Emotional } \\
\text { Independence } \\
\text { 2. Behavioral } \\
\text { Independence } \\
\text { 3. Value Independence }\end{array}$ & $\begin{array}{l}\text { Small and medium business } \\
\text { actors in Lubuk Pakam } \\
\text { District do not yet have } \\
\text { entrepreneurial } \\
\text { independence or good } \\
\text { business independence so } \\
\text { that they are not able and } \\
\text { effective in running a } \\
\text { business, so the results } \\
\text { obtained are not as expected. }\end{array}$ \\
\hline $\begin{array}{l}\text { Development of a Self } \\
\text { Efficacy Model to Increase } \\
\text { Business Independence in } \\
\text { MSMEs in Percut Sei Tuan } \\
\text { District }\end{array}$ & $\begin{array}{l}\text { 1. Level Dimension } \\
\text { 2. Generality } \\
\text { 3. Strength }\end{array}$ & $\begin{array}{l}\text { Self Efficacy has a positive } \\
\text { effect on business } \\
\text { independence for small and } \\
\text { medium enterprises. }\end{array}$ \\
\hline $\begin{array}{l}\text { The Development Model Of } \\
\text { Store Atmosfhere In } \\
\text { Culinary Business to } \\
\text { Increase of Purchasing } \\
\text { Interest of Society In The } \\
\text { Sub-District of Percut Sei } \\
\text { Tuan }\end{array}$ & $\begin{array}{l}\text { 1. Exterior } \\
\text { 2. General Interior } \\
\text { 3. Store Layout } \\
\text { 4. Interior Display } \\
\text { 5. Marketing Mix }\end{array}$ & $\begin{array}{l}\text { The store atmosphere } \\
\text { development model in the } \\
\text { culinary business to } \\
\text { increase people's buying } \\
\text { interest has a positive effect } \\
\text { by adding a supporting } \\
\text { variable, namely the } \\
\text { marketing mix. }\end{array}$ \\
\hline
\end{tabular}

\section{$\downarrow$}

Model of Social and Economic

Characteristics of MSMEs in Utilizing

Online Media to Increase People's

Purchasing Power in Batang Kuis District

\begin{tabular}{|l|c|c|}
\hline \multicolumn{3}{|c|}{ Research Plan 2021 } \\
\hline Activity & \multicolumn{1}{|c|}{ Indicator } & \multicolumn{1}{c|}{ Output } \\
\hline $\begin{array}{l}\text { Formulate a model of the Social } \\
\text { and Economic Characteristics of } \\
\text { MSMEs in the Utilization of }\end{array}$ & 1. MSME & $\begin{array}{l}\text { 1. Measurement of the Model of } \\
\text { Cocial and Economic } \\
\text { Characteristics of MSMEs in }\end{array}$ \\
\hline
\end{tabular}


Online Media to Increase People's Purchasing Power in Batang Kuis District, by:

1. Observing and analyzing the model of the social and economic characteristics of SMEs in the use of online media to increase the purchasing power of the community in Batang Kuis District

2. Trial and refinement of the model of the Social and Economic Characteristics of MSMEs in the Utilization of Online Media to Increase People's Purchasing Power in Batang Kuis District
2. Vertical and horizontal grid

3. Online Media (Facebook, Instagram, and Tiktok) the Utilization of Online Media to Increase People's Purchasing Power in Batang Kuis District

2. Printed Book of Research Results in the form of Monographs

3. Sinta Accredited National Journal Publication 1-3

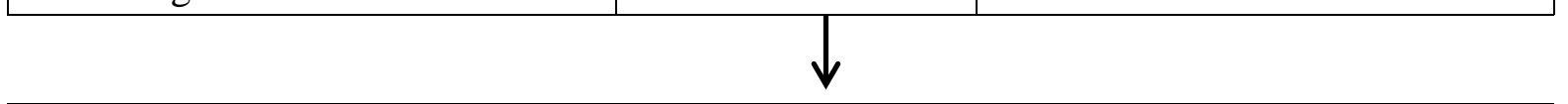

\begin{tabular}{|c|c|c|}
\hline \multicolumn{3}{|c|}{2022 Research Plan } \\
\hline Activity & Indicator & Output \\
\hline $\begin{array}{l}\text { Application and } \\
\text { socialization of the model of } \\
\text { the Social and Economic } \\
\text { Characteristics of MSMEs in } \\
\text { the Utilization of Online } \\
\text { Media to Increase People's } \\
\text { Purchasing Power in Batang } \\
\text { Kuis District. }\end{array}$ & $\begin{array}{l}\text { 1. Several supporting factors } \\
\text { that support online media } \\
\text { for MSMEs } \\
\text { 2. Several factors constrain } \\
\text { the use of online media } \\
\text { for SMEs } \\
\text { 3. The role } \\
\text { government/private } \\
\text { institutions is very } \\
\text { important for MSMEs }\end{array}$ & $\begin{array}{l}\text { 1. Supporting factors and } \\
\text { obstacles to the use of } \\
\text { online media for MSMEs } \\
\text { to increase people's } \\
\text { purchasing power in } \\
\text { Batang Kuis District } \\
\text { 2. Sinta Accredited National } \\
\text { Journal Publication 1-3 }\end{array}$ \\
\hline
\end{tabular}

Figure 2 Research Flowchart

\section{2) Research Design and Procedure}

This study uses the Research and Development (R\&D) method, in line with the objectives to be achieved in this study, namely model of social and economic characteristics of SMEs in the use of online media to increase people's purchasing power in Batang Kuis District. Data collection will be carried out, namely by: 
a) Identifying the problems of the social and economic characteristics of SMEs in the use of online media in the Batang Kuis sub-district. And analyze the problems from the data taken through the third questionnaire, evaluate and report the research results.

b) Make a design for the development of a model of the social and economic characteristics of SMEs in the use of online media to increase people's purchasing power. At this stage, a trial of the model of the social and economic characteristics of MSMEs is carried out to support the increase in people's purchasing power for the products produced in the Batang Kuis sub-district. Then carry out socialization and implementation as well as produce a book of teaching materials onmodel of social and economic characteristics of SMEs in the use of online media to increase people's purchasing power.

\section{3) Data collection technique}

a) This research uses literature study method, survey method in the form of a questionnaire for primary data, and by using secondary data.

b) Primary data collection was also carried out for testing the model of social and economic characteristics, socialization and implementation on small and medium enterprises located in Indonesia Batang Quiz District.

\section{4) Data analysis technique}

The data analysis technique in this study using Linear Regression aims to analyze the model of the social and economic characteristics of MSMEs to support increasing people's purchasing power for the products produced in the Batang Kuis District. Furthermore, this study also uses Structural Equation Modeling (SEM) based on Partial Least Square (PLS).

\section{RESEARCH RESULTS AND DISCUSSION}

\section{a. Research result}

\section{1) Structural Model Design}

The structural design model in SEM PLS and its manifest variables are as follows: 1) Exogenous latent variable Social Characteristics (X1) has 6 manifests (indicators), 2) Exogenous latent variable Economic Characteristics (X2) has 8 manifest variables (indicators), 3) Variables Social Media exogenous latent (X3) has 6 manifest variables (indicators) and 4) Endogenous latent variable Purchasing Power (Y) has 10 manifest variables (indicators).

In testing the hypothesis with Structural Equation Modeling Part Least Square (SEM PLS) by looking at the probability values and t-statistics. For probability values, the p-value with $5 \%$ alpha is less than 0.05 . The t-table value for $5 \%$ alpha is 1.96 . So the criteria for acceptance of the hypothesis is when t-statistics $>\mathrm{t}$-table.

\section{2) Outer Model Analysis}

Outer Model Analysis to provide specifications between the latent variable and its manifest variable, or in other words how each indicator relates to the latent variable. 


\section{Morfai journal \\ Multidiciplinary Output Research For \\ Actual and International Issue}

Outer model for reflective indicators is done by looking at Convergent Validity, where the value of loading factor on latent variables with indicators $>0.7$. Then Discriminant Validity, where the value of the cross loading factor which aims to determine whether the construct has a sufficient discriminant value by comparing the value of the loading factor on the intended construct must be greater than the loading value of the other constructs. Next, determine Composite Reliability, where the composite reliability value $>0.7$ has high reliability, followed by Average Variance Extracted (AVE). Expected AVE value $>0$,

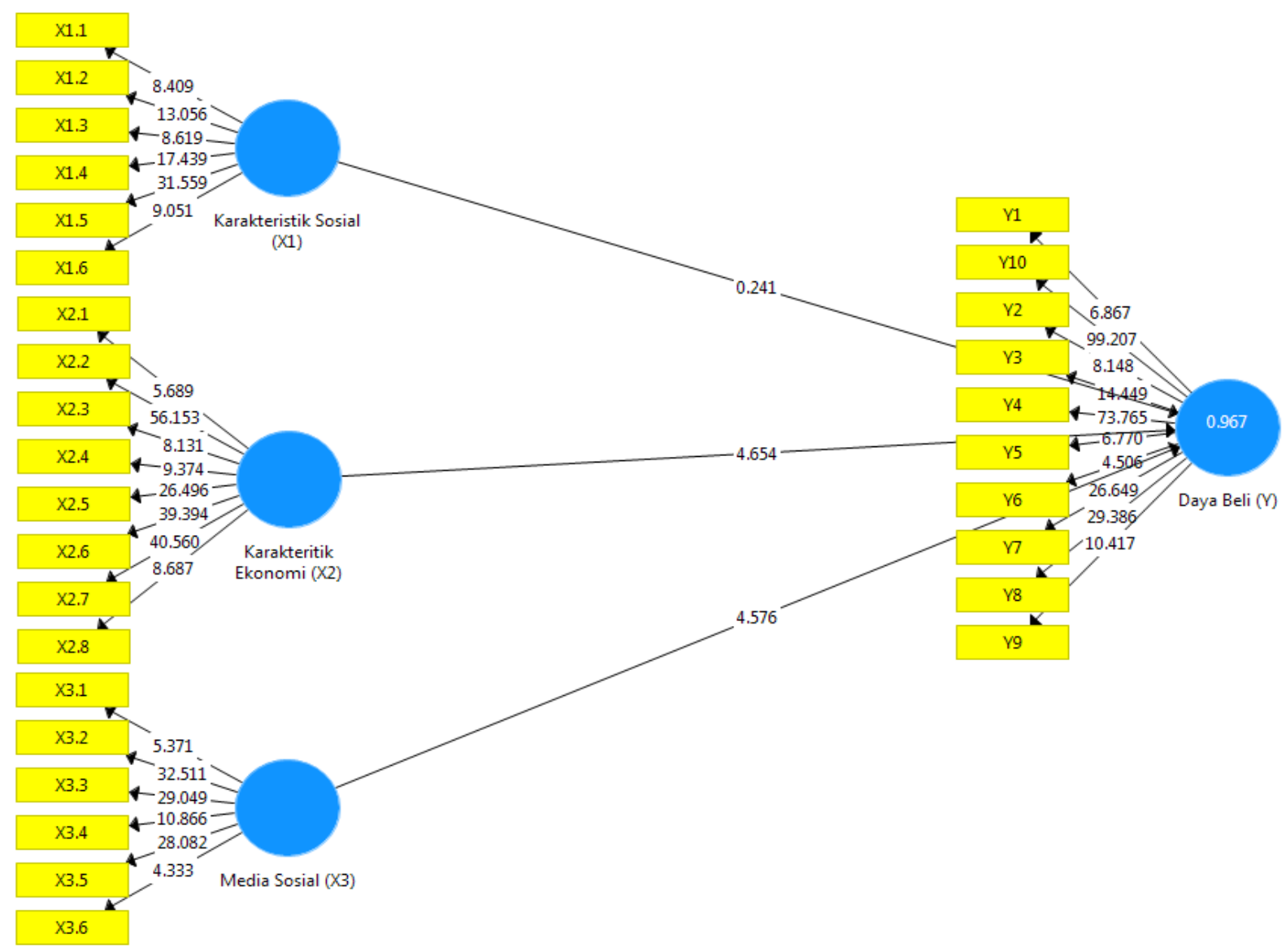

Figure 5 Output Model (Loading Factor) Research Model

The picture above shows that the loading factor of the latent variables $\mathrm{BE}, \mathrm{EKw}$, and $\mathrm{BP}$ has a loading factor below 0.6 so that it meets the Outer Model requirement > 0.6. According to Chin as quoted by Imam Ghozali, the outer loading value between 0.5 0.6 is considered sufficient to meet the convergent validity requirements and can be seen in Table 1 below: 
Table 1

\section{Outer Loading}

\begin{tabular}{|c|c|c|}
\hline Variable & Indicator & Outer Loading \\
\hline \multirow{6}{*}{ Social Characteristics (X1) } & $\mathrm{X} 1$ & 0.726 \\
\hline & $\mathrm{X} 2$ & 0.767 \\
\hline & $\mathrm{X} 3$ & 0.746 \\
\hline & $\mathrm{X} 4$ & 0.816 \\
\hline & $\mathrm{X} 5$ & 0.873 \\
\hline & X6 & 0.751 \\
\hline \multirow{8}{*}{ Economic Characteristics (X2) } & $\mathrm{X} 1$ & 0.574 \\
\hline & $\mathrm{X} 2$ & 0.929 \\
\hline & $\mathrm{X} 3$ & 0.722 \\
\hline & $\mathrm{X} 4$ & 0.711 \\
\hline & X5 & 0.902 \\
\hline & $\mathrm{X} 6$ & 0.906 \\
\hline & $\mathrm{X} 7$ & 0.928 \\
\hline & $\mathrm{X} 8$ & 0.715 \\
\hline \multirow{6}{*}{ Social Media (X3) } & $\mathrm{X} 1$ & 0.655 \\
\hline & $\mathrm{X} 2$ & 0.889 \\
\hline & X3 & 0.871 \\
\hline & $\mathrm{X} 4$ & 0.790 \\
\hline & $\mathrm{X} 5$ & 0.879 \\
\hline & X6 & 0.551 \\
\hline \multirow{10}{*}{ Purchasing Power (Y) } & Y1 & 0.636 \\
\hline & Y2 & 0.697 \\
\hline & Y3 & 0.837 \\
\hline & Y4 & 0.935 \\
\hline & Y5 & 0.666 \\
\hline & Y6 & 0.531 \\
\hline & Y7 & 0.905 \\
\hline & Y8 & 0.901 \\
\hline & Y9 & 0.774 \\
\hline & Y10 & 0.947 \\
\hline
\end{tabular}

Then the convergent validity value can be seen from the Average Variance Extracted (AVE) value, in this study the AVE value of each construct is above 0.5 so that there is no convergent validity problem in the tested model, as shown in Table 1. 
Table 2

Average Variant Extracted (AVE)

\begin{tabular}{|c|c|}
\hline Variable & AVE \\
\hline Social Characteristics (X1) & 0.610 \\
\hline Economic Characteristics (X2) & 0.653 \\
\hline Social Media (X3) & 0.613 \\
\hline Purchasing Power (Y) & 0.632 \\
\hline
\end{tabular}

Since there is no problem with convergent validity, then the next step is to test discriminant validity, by comparing the value of $\mathrm{Cr} 2 \mathrm{AVE}$ with the correlation value between constructs.

Table 3

\section{Output Discriminant Validity}

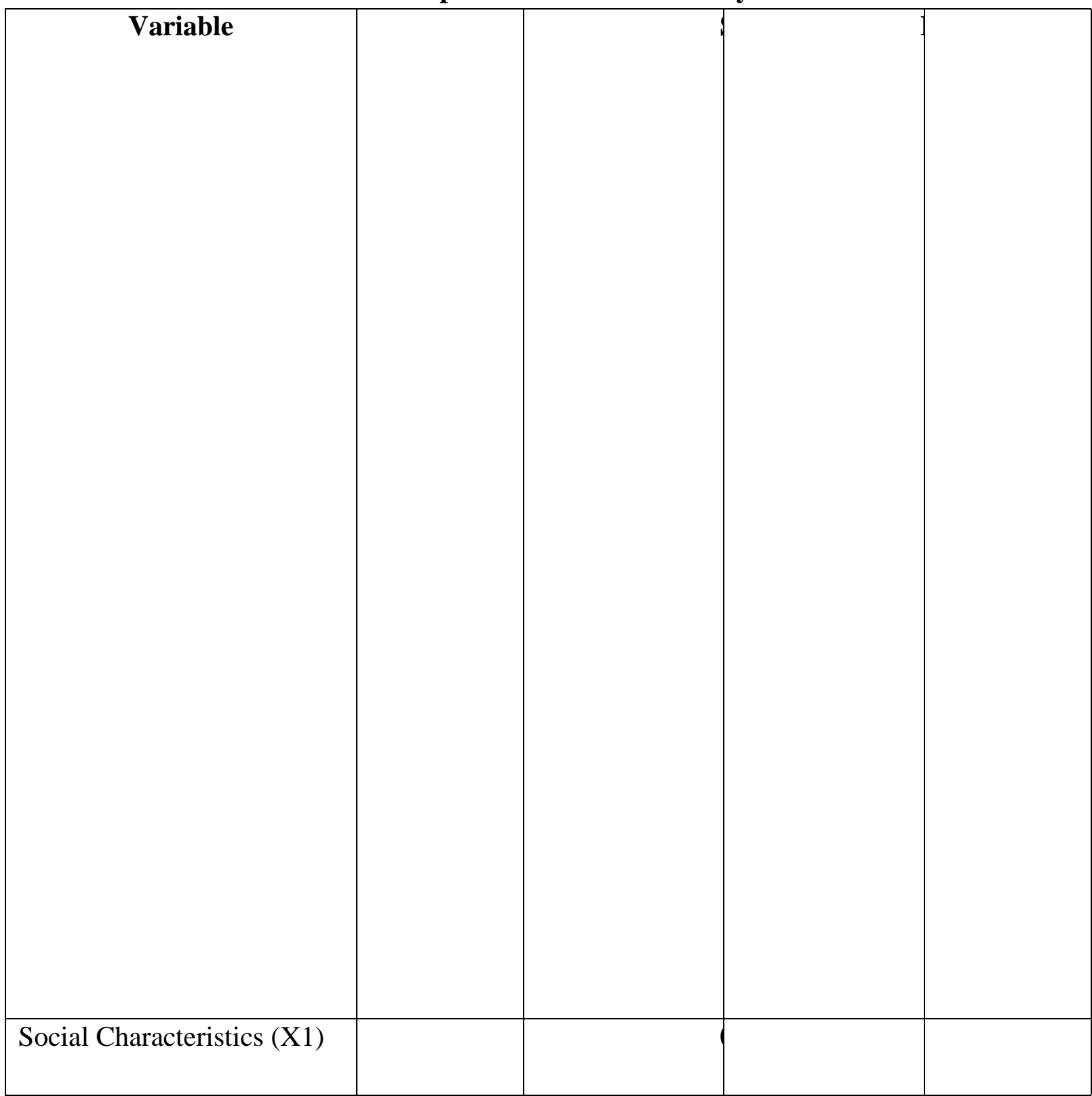




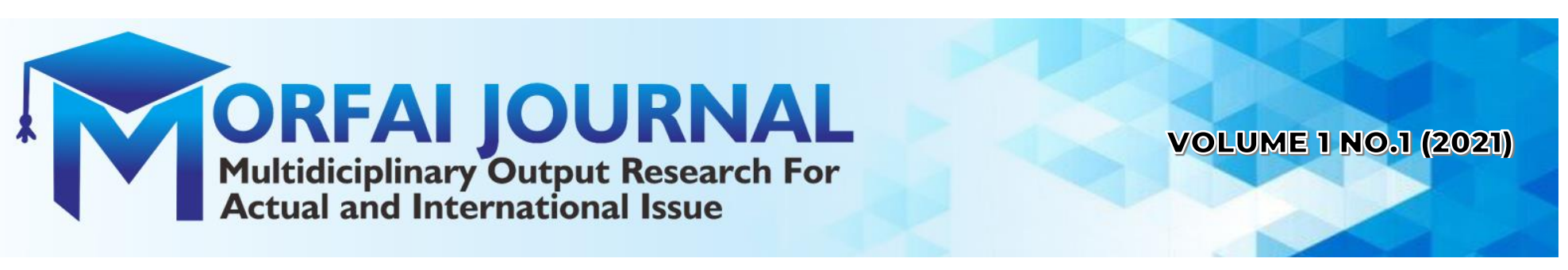

\begin{tabular}{|l|l|l|l|l|}
\hline & & & & \\
\hline $\begin{array}{l}\text { Economic Characteristics } \\
\text { (X2) }\end{array}$ & & & & \\
\hline Social Media (X3) & & & & \\
\hline Purchasing Power (Y) & & & & \\
& & & & \\
\hline
\end{tabular}

Table 2 shows the value of the square root of AVE. From the table above, it can be seen that the value of the square root of $\operatorname{AVE}(0.610 ; 0.653 ; 0.613$ and 0.632$)$ is greater than the correlation of each construct. Another method that can be used to test discriminant validity is to look at the cross loading table. In addition, the reflective indicators need to be tested for discriminant validity by comparing the values in the cross loading table. An indicator is declared valid if it has the highest loading factor value to the intended construct compared to the loading factor value to other constructs.

Table 4

Composite Reliability

\begin{tabular}{|c|c|}
\hline Variable & Composite Reliability \\
\hline Social Characteristics (X1) & 0.903 \\
\hline Economic Characteristics (X2) & 0.936 \\
\hline Social Media (X3) & 0.903 \\
\hline Purchasing Power (Y) & 0.943 \\
\hline
\end{tabular}

Based on the data presented in table 4 above, it can be seen that the composite reliability value of all research variables is $>0.6$. These results indicate that each variable has met composite reliability so that it can be concluded that all variables have a high level of reliability. 
Table 5

Cronbach Alpha

\begin{tabular}{|c|c|}
\hline Variable & Cronbach's Alpha \\
\hline Social Characteristics (X1) & 0.874 \\
\hline Economic Characteristics (X2) & 0.919 \\
\hline Social Media (X3) & 0.874 \\
\hline Purchasing Power (Y) & 0.930 \\
\hline
\end{tabular}

Inner structural model testing on PLS SEM was carried out by using the R-squared (R2) test and the significance test through path coefficient estimation. The R-squared (R2) value aims to measure how much influence the independent latent variable has on the dependent latent variable. The R-squared (R2) value in this study is 0.965 , this indicates that the model is categorized as very good because it is greater than 0.67 .

Table 6

R-Square Nilai Value

\begin{tabular}{|c|c|}
\hline Variable & R-Square Nilai Value \\
\hline Purchasing Power(Y) & 0.967 \\
\hline
\end{tabular}

Based on the data presented in table 6 above, it can be seen that the R-Square value for the Y purchasing power variable is 0.967 . Obtaining this value explains that the percentage of purchasing power can be explained by the variability of X1, X2, and X3 of $96.70 \%$.

The goodness of fit assessment is known from the Q-Square value. The Q-Square value has the same meaning as the coefficient determination (R-Square) in regression analysis, where the higher the Q-Square, the model can be said to be better or more fit with the data. The results of the calculation of the Q-Square value are as follows:

Q-Square $=1-[(1-\mathrm{R} 21)]$

$$
\begin{aligned}
& =1-[(1-0.967)] \\
& =1-(0.033) \\
& =0.967
\end{aligned}
$$

Before testing the hypothesis, it is known that the value of the T-table for the $95 \%$ confidence level $(\alpha 5 \%)$ and the degrees of freedom $(\mathrm{df})=\mathrm{n}-4=75-4=71$ is 1.66660 . Hypothesis testing for each latent variable relationship is shown as follows:

\begin{tabular}{|c|c|c|c|c|c|c|}
\hline $\begin{array}{l}\text { Hypothesis } \\
\text { Effect }\end{array}$ & $\begin{array}{l}\text { Ori } \\
\text { ginal } \\
\text { Sample } \\
(0)\end{array}$ & $\begin{array}{r}\text { S } \\
\text { ample } \\
\text { Mean } \\
\text { (M) }\end{array}$ & $\begin{array}{c}\text { Stan } \\
\text { dard } \\
\text { Error } \\
\text { (STERR) }\end{array}$ & $\begin{array}{r}T- \\
\text { Statistics }\end{array}$ & $\begin{array}{r}P \\
\text {-Values }\end{array}$ & $\begin{array}{l}\text { Res } \\
\text { ults }\end{array}$ \\
\hline $\begin{array}{c}\text { Social } \\
\text { Characteristics }=>P\end{array}$ & $0.015^{-}$ & $0.018^{-}$ & $3^{0.06}$ & $41^{0.2}$ & $810^{0 .}$ & $\begin{array}{l}\text { Reje } \\
\text { cted }\end{array}$ \\
\hline
\end{tabular}

Table 7

T-Statistics and P-Values 


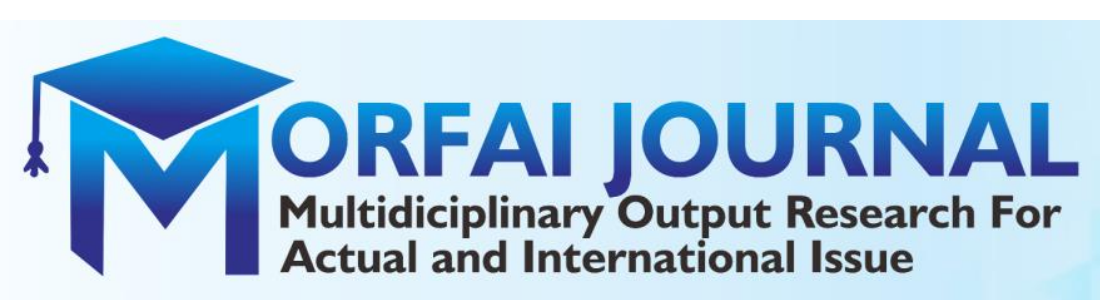

VOLUME I NO.1 (2021)

\begin{tabular}{|c|c|c|c|c|c|c|}
\hline $\begin{array}{l}\text { urchasing Power } \\
\text { (H1) }\end{array}$ & & & & & & \\
\hline $\begin{array}{c}\text { Economic } \\
\text { Characteristics }=>P \\
\text { urchase Power } \\
(\mathrm{H} 2)\end{array}$ & $2^{0.58}$ & $566^{0 .}$ & $5^{0.12}$ & $\begin{array}{l}4^{4,6} \\
54^{4}\end{array}$ & $000^{0 .}$ & $\begin{array}{l}\text { Acce } \\
\text { pted }\end{array}$ \\
\hline $\begin{array}{c}\text { Social } \\
\text { Media=>Purchasin } \\
\text { g Power }(\mathrm{H} 3)\end{array}$ & $1^{0.43}$ & 450 & $\begin{array}{l}0.09 \\
4^{0}\end{array}$ & $76^{4,5}$ & $000^{0 .}$ & $\begin{array}{l}\text { Acce } \\
\text { pted }\end{array}$ \\
\hline
\end{tabular}

The output results in Table 7 T-statistics for Hypothesis 1, the effect of Social Characteristics on the Purchasing Power variable is $0.241<1.66660$, with an insignificant value of probability $>0.000$ and the original sample estimate value shows a negative value of -0.015 which indicates that the direction of the variable relationship Social Characteristics of the Purchasing Power variable is negative, thus Hypothesis 1 in this study can be rejected, meaning that in this study the latent variable of Social Characteristics and its indicators has no significant effect on Purchasing Power.

Hypothesis 2 T-statistics for the effect of Economic Characteristics on Purchasing Power of $4.654>1.66660$, and the original sample estimate value shows a positive value of 0.582 which indicates that the direction of the relationship between the variables of Economic Characteristics on Purchasing Power is positive, thus Hypothesis 2 in this study acceptable means that in this study the latent variable of Economic Characteristics and its indicators significantly influence purchasing power.

Then Hypothesis 3 T-statistics for the influence of Social Media on Purchasing Power of $4.576>1.66660$, and the original sample estimate value shows a positive value of 0.431 which indicates that the direction of the relationship of Social Media variables to Purchasing Power is positive, thus Hypothesis 3 in this study This is acceptable, meaning that in this study the latent variables of Social Media and their indicators have a significant effect on Purchasing Power.

\section{b. Discussion}

The discussion in this study will be explained through the hypothesis of the research and adapted to the data analysis that has been done previously, for more details, the discussion can be described as follows:

\section{1) Effect of Social Characteristics (X1) on Purchasing Power (Y)}

Based on the results of the research above, it can be concluded that social characteristics have no effect on purchasing power due to the influence of the digital era which is already widespread in buying and selling interactions, so that direct social interaction is very rarely carried out.

according to (Febyanto, 2016)The development of the social character of society is very rapid in this modern era. Social development occurs either through direct social interaction 
or through social media. Some people form a certain social group in society, there are also those who create a certain group on social media such as Facebook, WhatsApp, BBM and so on. Social character can affect the purchasing power of fellow individuals when interacting with each other.

The results of this study are in line with previous research conducted by (Thamrin, Herman, \& Hanafi, 2012) Partially there is no influence of labor and education or grouped in social characteristics on the income level of areca nut farming, this is supported by the value of $\mathrm{t}$ - count $<\mathrm{t}$ - table.

The results of this study are in line with previous research conducted (Rangkuti, Siregar, Thamrin, \& Andriano, 2014)there is no significant or significant effect between capital, farming experience and the number of dependents called social characteristics on corn farming income. The results of the t-test obtained $\mathrm{t}$-count $<\mathrm{t}$-table at the $95 \%$ confidence level. Thus $\mathrm{H} 1$ is rejected and $\mathrm{H} 0$ is accepted.

The results of this study are inversely proportional to previous research conducted (Moammad \& Hufron, 2019) Based on the results of data analysis, it can be stated that social groups have a significant effect on purchasing decisions. Social group is one of the factors in consumer purchasing decisions.

\section{2) The Effect of MSME Economic Characteristics (X2) on Purchasing Power (Y)}

Based on the results of the research above, it can be concluded that the economic characteristics of MSMEs affect the purchasing power of the community. This is due to the influence of the community's economy which influences the purchase of a product. The level of the economy determines how the community meets their needs, so that when the economic characteristics of the community are fulfilled it will affect the purchasing power of the community and can increase the income of sellers.

The results of this study are in line with previous research conducted (Arifianto \& Setiyono, 2019)shows that economic growth affects the distribution of income in Indonesia. The effect is positive and significant, the contributing factors are misdirected subsidies, the low level of equity in education and mastery of technology.

The results of this study are in line with previous research conducted (Sedyaningrum, Suhadak, \& Nuzula, 2016)The hypothesis which states that simultaneously exports, imports and the economic level affect people's purchasing power is acceptable. The economic condition of a country will also affect its per capita income. The increase in economic growth from year to year will cause national production to increase, but the increase in economic growth that is not matched by suppression of the population will not have an impact on per capita income.

The results of this study are in line with previous research conducted (Octavia, 2015)that there is an influence of socio-economic factors on the behavior of milk consumption in adolescents. The influencing factors include economic factors including family income and education. 


\section{3) The Effect of Online Media (X3) on Purchasing Power (Y)}

Based on the results of the research above, it can be concluded that social media affects people's purchasing power. This is due to the influence of social media which has been widely used by the community in carrying out activities including buying the necessary needs through social media.

The results of this study are in line with previous research conducted (Rudyanto, 2018)stated that social media networks have a significant influence on consumer purchase intentions and consumer engagement. This study also proves that consumer involvement acts as a mediator between social media network marketing and consumer purchase intentions.

The results of this study are in line with previous research conducted (Rohani, Hufron, \& Rizal, 2019)Effect of Social Media on Repurchase Interest Based on the test results indicate that social media is directly and significantly dominant towards the purchase intention of Glow products. This is because the value of sig. H3 is accepted if it is less than the specified significance level.

The results of this study are in line with previous research conducted (Rosyida, Putri, Umami, \& Sudalhar, 2018)Gives the result that the media has a positive effect on buying interest in Samsung products. Social media can be used to market the goods and services of an agency and company, of course, at a relatively affordable cost.

\section{4) The Effect of Social Characteristics (X1), Economic Characteristics of SMEs (X2), and Online Media (X3) on Purchasing Power (Y)}

Based on the results of the research above, it can be concluded that the characteristics of the economy and social media can affect purchasing power to increase the income of people who have MSME businesses.

The results of this study are in line with previous research conducted (Sumerta, Redianingsih, Pranawa, \& Indahyani, 2020)that the use of Social Media partially positive and significant effect on Entrepreneurial Interest. By increasing entrepreneurship, it can increase the income obtained from the sales made so that people's purchasing power also increases.

The results of this study are in line with previous research conducted (Andrianyta, Ulfah, \& Hermawan, 2016)Social impact relates to the impact on the family and regional economy. Improving the quality of yard management, especially in rural areas, gives positive results. Judging from the sale of the product, the selling price of the product is always profitable and the market demand is high. The on-site sales mechanism (buyers come directly) opens up opportunities for the area to be upgraded to become an agro-tourism area. In this case, it needs to be supported by planning and supporting infrastructure from the local government.

The results of this study are in line with previous research conducted (Hagang, 2019)states that the innovation variable (X1), social media variable (X2) and price variable (X3) simultaneously have a significant influence on buying interest (Y) on Geprek Express Samarinda consumers, this can be seen from the analysis results that $F$ count has a value of 
37.478 and when compared with the F table value of 2.70 , it can be seen that the calculated $\mathrm{F}$ is greater than the $\mathrm{F}$ table, or by calculating $\mathrm{F}$ arithmetic $=37.478>\mathrm{F}$ table $=2.70$. This means that there is a significant relationship between innovation, social media, and price on consumer buying interest in Geprek Express Samarinda.

\section{CONCLUSIONS AND SUGGESTIONS}

\section{Conclusion}

Based on the results of research and discussion on Social Characteristics, Economic Characteristics, and Social Media on People's Purchasing Power in Batang Kuis District, it can be concluded as follows:

1) Based on research conducted on community in Batang Kuis Kecamatan sub-district, then it can be concluded that Social Characteristics does not have a significant effect on Purchasing Power.

2) Based on research conducted on community in Batang Kuis Kecamatan sub-district, then it can be concluded that Economic Characteristics has a significant effect on purchasing power.

3) Based on research conducted on community in Batang Kuis Kecamatan sub-district, then it can be concluded that Social media has a significant effect on purchasing power.

4) Based on research conducted on community in Batang Kuis Kecamatan sub-district, then it can be concluded that Social Characteristics, Economic Characteristics, and Social Media does not have a significant effect on Purchasing Power.

\section{Suggestion}

Based on the conclusions above, in this case the author can suggest the following:

1) In improving Social Characteristics, Economic Characteristics, and Social Media, as a society, people can increase knowledge about the use of social media (online) and also understand social and economic characteristics to increase purchasing power and also increase income.

2) The community in Batang Kuis District, must pay attention to the factors that influence Social Characteristics, Economic Characteristics, and Social Media in order to create a better purchasing power.

\section{REFERENCES}

Andrianyta, H., Ulfah, A., \& Hermawan, H. (2016). The Impact of Yard Utilization in Social and Economic Perspectives in East Kalimantan. Proceedings of the National Seminar on Agricultural Technology Innovation, 1701-1717.

Arifianto, W., \& Setiyono, I. (2019). The Effect of Economic Growth on Income Distribution in Indonesia. UNESA : State University of Surabaya, pp. 1-16.

Diah AP, Partini, SP (2018). Yogyakarta Socioprenerus Challenge in the Era of Comm 3.0 Prophetic. Journal of Communication, 3, 12-25. 


\section{ORFAI JOURNAL \\ Multidiciplinary Output Research For \\ Actual and International Issue}

Eva Margaret Sarah Nainggolan, KFO (2019). The Influence of Brands and Advertising on Consumer Purchasing Power at Pt Indako Trading Coy Krakatau Medan (Case Study on Honda Consumers Who Purchased Cb150 Units). Mutiara Management Journal, Vol.4No.2,

Febyanto, C. (2016). Analysis of the Effect of Social Groups and Families on Children's Psychosocial Development (Case Study on Students Sdn Wonokerso 01 Malang Regency). JPDN: Archipelago Basic Education Journal, 2(1), 10-20.

Ferdinand, C. (2008). Regional Marketing and Innovation System in The Periphery: The case of Quebec. International Journal of Innovation Management.

Hagang, LV (2019). The Influence of Innovation, Social Media, and Prices on Consumer

Purchase Interest at Geprek Express Samarinda. EJournal of Business Administration, 7(1), 222-235.

Husin, D., Wijaya, I., Dewi, N., \& Hilmi. (2019). PRODUCT PROMOTION USING ONLINE SOCIAL MEDIA ON SMALL TRADERS IN THE CITY OF LHOKSEUMAWE. Vocational Journal, 3(1).

Kaplan, Andreas, M. and HM (2010). Users of the world unit! The challenges and opportunities of Social Media. Business Horizons.

Kominfo. (2013). Kemkominfo: Internet Users in Indonesia Reach 82 Million.

Kotler, F. (2003). SME Development in Countries of Central Asia: Constrains, Cultural Aspects and Role of International Assistance. In Vienna (Ed.), United Nations Industrial Development Organizations. V.

Lathifah, Z., \& Lubis, DP (2018). The Relationship between the Use of Social Media and the Development of Culinary Small and Medium Enterprises in the Greater Solo Region. Journal of Development Communication, 16.

Madura, J. (2000). International Financial Management. Volume 1, Fourth Edition. Jakarta: Erlangga.

Moammad, \& Hufron, M. (2019). The Influence of Social Groups and Lifestyles on the Decision to Purchase Go-Jek Services (Case Study on Students of the Faculty of Economics and Business, Islamic University of Malang). E- Journal of Management Research, MANAGEMENT STUDY, 8(21), 39-48.

Moch Hari Purwidiantoro, Dany Fajar Kristanto SW, WH (2016). THE EFFECT OF SOCIAL MEDIA USE ON THE DEVELOPMENT OF SMALL MEDIUM ENTERPRISES (SMEs). EKA CIDA Journal, Vol. 1 No.

Mohamad Trio Febriyantoro, DA (2018). Utilization of Digital Marketing for Micro, Small and Medium Enterprises in the Era of the Asean Economic Community. JMD: Dewantara Management Journal, 1(2).

Moriansyah. (2015). Marketing through social media: antecedents and consequences. Journal of Communication and Public Opinion Research, Vol.19 No.

Octavia, SA (2015). The Influence of Socio-Economic Factors on Milk Consumption Behavior in Adolescents. Majority, 4(8), 89-92.

Putong, I. (2010). Non-Functional Group Member Demand Factors Against Demand (series 
1). Jakarta: Bina Nusantara University.

Rafsanjani, RM \& H. (2018). MARKETING STRATEGY THROUGH ONLINE MEDIA ON

HOME BUSINESS PRODUCTS OF ONION CRUPUK AND Breadfruit chips in CENDORO VILLAGE, KEC. REGIONAL CROSS. TUBAN. Masharif Al-Syariah Journal: Journal of Islamic Economics and Banking, Vol. 3, No.

Rangkuti, K., Siregar, S., Thamrin, M., \& Andriano, R. (2014). The Influence of SocioEconomic Factors on Corn Farmers' Income. 2Agrium, 19(1), 52-58.

Rohani, S., Hufron, M., \& Rizal, M. (2019). The Influence of Social Media and Celebrity Endorsers on Repurchase Interest With Brand Trust As an Intervening Variable (Case Study on Customers of Ms Glow Aesthetic Clinic Malang). E - Journal of Management Research STUDY OF MANAGEMENT, 9(10), 48-65.

Rosyadi. (2019). The Effect of Purchasing Power and Unemployment on Poverty Levels in Indonesia in 2012-2017. SATIESP Proceedings.

Rosyida, FN, Putri, MW, Umami, A., \& Sudalhar. (2018). The Effect of Brochure Print Media and Facebook Social Media on Patient Purchase Interest Using Outpatient Services at Ibnu Sina Hospital Bojonegoro. Journal of Hospital Science, 2(2), 9-15.

Rudyanto. (2018). The Effect of Social Media Network Marketing and Consumer Linkage to Consumer Purchase Intentions. Journal of Service Management and Marketing, 11(2), 177-200.

Sedyaningrum, M., Suhadak, \& Nuzula, NF (2016). The Effect of Total Export Value, Import and Economic Growth on Exchange Rate and People's Purchasing Power in Indonesia Study at Bank Indonesia Period 2006:IV-2015:III. Journal of Business Administration (JAB), 34(1), 114-121.

Setiarso, B. (2006). Knowledge Management and Intellectual Capital for SME Empowerment. Technology and Information Development Conference. Bandung.

Spencer, LM, and SAM (1993). Competence at Work. Wiley and Son, Inc.: Models for Superior Performance.

Sumerta, IK, Redianingsih, NK, Pranawa, IMB, \& Indahyani, DNT (2020). The Influence of the Level of Social Media Use and Motivation on Interest in Entrepreneurship in College Management Study Program Students in Denpasar City. E-Journal of Economics and Business, Udayana University, 9(7), 627-652.

Sutardji. (2009). Demographic and Socio-Economic Characteristics of Scavengers. Department of Geography FIS - UNNES, 6.

Thamrin, M., Herman, S., \& Hanafi, F. (2012). The Influence of Socio-Economic Factors on the Income of Areca Farmers. Agrium, 17(2), 85-94. 